\title{
MULTIPLE INTELLIGENCES DAN PENGAMBILAN KEPUTUSAN DALAM LINGKUNGAN PENGARUH BIROKRAT-PROFESIONAL (CONTESTED ZONE) DI PERGURUAN TINGGI
}

\author{
Herculanus Bahari-Sindju ${ }^{1}$
}

Artikel nonpenelitian dengan judul "Multiple Intelligences dan Peng-ambilan Keputusan dalam Lingkungan Pengaruh Birokrat-Profesional (Contested Zone) di Perguruan Tinggi (PT)" ini merupakan salah satu solusi untuk menghindari konflik yang mungkin terjadi akibat perbe-daan kepentingan kelompok di PT. Sehubungan dengan itu, isi artikel ini menggambarkan kebutuhan PT dalam lingkungan bersama kelom-pok birokrat dan profesional yang mungkin sebagai memicu konflik. Melalui analisis proses pengambilan keputusan, mulai dari perumusan alternatif yang dilengkapi data (sebagai pertimbangan, keuntungan, dan dampak negatif yang akan terjadi akibat produk keputusan), sampai dengan negosiasi untuk mencari dukungan terhadap keputusan yang ditawarkan. Berdasarkan hasil analisis tersebut penulis berupaya menempatkan pilar-pilar multiple intelligences dalam langkah-langkah proses seperti uraian selanjutnya.

Kata kunci: multiple intelligences, pengambilan keputusan, lingkungan pengaruh birokrat-profesional dan perguruan tinggi.

Secara klasik, penyelenggaraan perguruan tinggi (PT) sebagai organisasi melibatkan kelompok birokrat dan profesional. Pada prinsipnya, kelompok birokrat diwakili rektor, para dekan, para pembantu dan stafnya, sedangkan kelompok profesi-onal terdiri dari para dosen, instruktor, laboran dan pustakawan. Kedua kelompok masing-masing memiliki kebutuhan atau kepentingan. Karena itu sering menimbul-kan konflik yang akhirnya merugikan mahasiswa dan masyarakat.

Kondisi tersebut mengundang pemikiran bagaimana mengembangkan proses pengambilan keputusan yang mempertimbangkan

\footnotetext{
${ }^{1}$ Herculanus Bahari-Sindju adalah dosen Jurusan Ilmu Pendidikan FKIP-UNTAN Pontianak
} 
empati kedua belah pihak yang berhadapan. Artinya, proses pengambilan keputusan tidak hanya mengutamakan rasional semata, tetapi juga memperhatikan aspek kecerdasan lain. Sehubungan itu, penulis termotivasi untuk mengangkat bagaimana multiple intelligences (MI dima-inkan dalam proses pengambilan keputusan terhadap kepentingan bersama kelompokkelompok dalam penyelenggaraan suatu PT.

Tentunya, keinginan mengangkat topik tersebut cukup beralasan. Terutama dikaitkan dengan temuan tentang peran kecerdasan emosional terhadap kinerja (Goleman, 1999). Menurut penelitian tersebut, ternyata interpersonal intelligence dan intra-personal intelligence (dua dari delapan pilar MI), ekuivalen dengan kecer-dasan emosional (Goleman, 1999) lebih berperan daripada kecerdasan intelektual atau keahlian teknis dalam menentukan siapa yang akan menjadi bintang dalam suatu pekerjaan (apapun). Karena analisis hubungan kinerja dan kecakapan dilakukan dalam konteks bisnis baru berdasarkan temuan-temuan penelitian 25 tahun terakhir, jelas penelitian tersebut memiliki tingkat keyakinan yang tinggi. Selanjutnya, bagaimana multiple intelligences diperankan dalam proses peng-ambilan keputusan, diuraikan dalam sistimatika: (1) pengaruh kelompok dan kebu-tuhan PT, (2) berbagai kebutuhan PT, (3) multiple intelligences, (4) proses pengam-bilan keputusan, (5) peran MI dalam proses pengambilan keputusan.

\section{PENGARUH KELOMPOK DAN KEBUTUHAN PT Pengaruh Kelompok Birokrat-Profesional di PT}

Dari aspek kepentingan kelompok birokratik dan profesional, PT seolah terbentuk dari dua lingkungan kekuatan yang saling berhadapan (the professional-bureaucratic interface). Dalam konteks tujuan organisasi, kedua kekuatan tersebut membangun model lingkungan interaksi atau the interacting spheres model (Hanson, 1991: 93) yang mengakar pada tujuan PT. Sehubungan dengan itu kedua kelompok sangat berperan dan menentukan keefektifan proogram suatu PT.

Bagaimanapun, dalam lingkungan interaksi terdapat kepentingan bersama antara kelompok birokrat dan profesional. Hanya, demi kepentingan kelompoknya, masing-masing termotivasi untuk pemperjuangkannya. Sehubungan itu, lingkungan interaksi dikenal sebagai contested zone, yakni suatu daerah dengan potensi kepen-tingan yang harus diperjuangkan. Dalam banyak hal kemungkinan kedua belah pihak dapat saling memahami, sehingga gampang menemukan solusi yang menguntungkan organisasi. 
Dalam kenyataannya, tidak sedikit yang menemukan jalan buntu tanpa alternatif yang jelas. Hal demikian, menjadikan contested zone daerah rawan konflik

yang memerlukan pertimbangan arif untuk suatu keputusan yang produktif. Dalam hubungan itu, kedua kelompok yang berkepentingan di PT perlu mengembangkan cara-cara memperjuangkan kebutuhan dalam sentuhan kepentingan organisasi.

\section{Berbagai Kebutuhan PT}

Dalam praktiknya, rektor tidak dapat melepaskan diri dari kebijakan yang berkaitan dengan kepentingan politik nasional atau kelompok tertentu, seperti Dikti. Sering kali, demi kepentingan atau kebijakan atasan (Dirjen Dikti), keputusan rektor menimbulkan konflik karena tidak seirama dengan kepentingan profesional dan masyarakat. Malah tidak jarang, demi kepentingan pribadi dan kolegial dapat terjadi keputusan yang kontroversial dengan buntut berkepanjangan.

Untuk mencapai keputusan dalam lingkungan bersama (contested zone), kedua belah pihak perlu berjuang untuk menghasilkan keputusan yang memuaskan kedua belah pihak. Khususnya, pihak yang berperan sebagai faktor governance yang mengontrol proses pembuat keputusan, yakni dosen atau yang mewakili, maupun pihak decision making (pengambilan keputusan oleh rektor atau senat). Dengan kepemimpinan yang demikian, PT dapat mewujudkan pelayanan yang memuaskan, baik secara internal maupun eksternal.

Birokrat yang sudah diterapkan sejak Mesir dan Romawi Kuno (Blau, \& Meyer, 2000) adalah salah satu kelompok yang berperan di PT. Sesuai sistem yang dianut, pengelolaan dan pengembangan PT lebih disesuaikan dengan kepentingan pemerintah pusat atau kepentingan nasional. Sehubungan dengan itu, PT dapat dikatakan menjadi alat untuk menanamkan ideologi yang mendukung kekuasaan. Harapan tersebut telah mendorong kelompok birokrat, atas nama institusional melakukan intervensi dalam wilayah tanggung jawab kelompok profesional. Seperti, pemaksaan beberapa mata kuliah yang tidak relevan dengan kebutuhan mahasiswa merupakan contoh kontroversi yang tidak efektif.

Bagaimanapun, untuk mencapai tujuan yang komprehensif, seperti terumus-kan pada tujuan pendidikan nasional (UU Sisdiknas No. 20 Tahun 2003), birokrat memerlukan dukungan kelompok profesional. Begitulah, kelompok profesional yang bertanggung jawab dalam kegiatan studi mahasiswa memandang PT sebagai lembaga pelayanan masyarakat. 
Dengan demikian, relevansi program atau kegiatan pembela-jaran dengan kebutuhan masyarakat menjadi tanggung jawab kelompok profesional.

Menurut sistem yang berlangsung, jelas bahwa proses pengelolaan dan penyelenggaraan PT dilaksanakan di bawah dua pengaruh. (1) Kelompok birokrat, yakni pimpinan puncak, lembaga dan fakultas yang mewaliki kepentingan pemerintah dan atau yayasan; (2) kelompok profesional, yakni dosen yang diwakili dalam keanggotaan senat. Dengan kata lain, pengelolaan PT selalu berada dalam dua pengaruh kepentingan yang mewakili kelompok birokrat dan profesional dengan kepentingan masingmasing.

Untuk menghindari konflik, kedua belah pihak perlu mengidentifikasi kebu-tuhan yang dapat ditangani masing-masing, dan bidang-bidang yang harus ditangani bersama oleh kedua belah pihak. Karena itu kepemimpinan PT yang baik nampak pada kemampuannya mewujudkan keseimbangan antara kepentingan kelompok dengan kepentingan organisasi.

PT sebagai penyelenggara pendidikan, berfungsi mempersiapkan mahasiswa agar mampu merancang, mengelola dan memanfaatkan sumber daya lingkungan untuk meningkatkan kualitas hidup. Dalam arti luas, kualitias hidup berkaitan dengan kesejahteraan diri (mahasiswa) maupun masyarakat dan negara umumnya. Untuk mencapai tujuan tersebut, pendidikan yang diselenggarakan PT harus didasarkan pada kebutuhan pelayanan.

Secara umum, kebutuhan pelayanan PT berorientasi pada kegiatan pembela-jaran, sumber daya pendukung, anggaran, kelangsungan hidup SDM, sarana dan prasarana yang mendukung program. Mengacu pada Samuel B. Bacharach (1981), Hanson (1991) mengelompokkan kebutuhan pendidikan dalam tiga kategori dengan rincian berikut. (1) Allocation Decisions, [budgeting, scheduling, personnel],

Kebutuhan Contested Zone antara Pengaruh Birokrat dan Profesional

\begin{tabular}{|c|c|c|}
\hline $\begin{array}{c}\text { Lingkungan Pengaruh } \\
\text { Rektor }\end{array}$ & Contested Zone & $\begin{array}{c}\text { Lingkungan Pengaruh } \\
\text { Dosen }\end{array}$ \\
\hline $\begin{array}{l}\text { 1.1. Pertanggungjawaban } \\
\text { anggaran umumnya } \\
\text { 1.2. Penjadwalan } \\
\text { penggunaan fasilitas } \\
\text { kampus } \\
\text { 1.3. Penggolongan atau } \\
\text { peng-administrasian } \\
\text { pegawai }\end{array}$ & $\begin{array}{l}\text { 1.1. Penggunaan uang } \\
\text { proyek khusus (bola } \\
\text { kaki, kompor) } \\
\text { 1.2. Persiapan jadwal } \\
\text { kegiatan utama } \\
\text { 1.3. Pensertifikasian } \\
\text { personil }\end{array}$ & $\begin{array}{l}\text { 1.1. Belanja khusus } \\
\text { jurusan (buku, dan } \\
\text { fieldtrips) } \\
\text { 1.2. Penempatan } \\
\text { mahasiswa di } \\
\text { kelas-kelas } \\
\text { bantuan. } \\
\text { 1.3. Penetapan ketua } \\
\text { jurusan }\end{array}$ \\
\hline
\end{tabular}




\begin{tabular}{|c|c|c|}
\hline $\begin{array}{l}\text { 2.1. Penggunaan polisi } \\
\text { untuk keamanan } \\
\text { kampus } \\
\text { 2.2. Pengesyahan } \\
\text { kehadirian polisi } \\
\text { 2.3. Disiplin kampus }\end{array}$ & $\begin{array}{l}\text { 2.1. Supervisi kampus } \\
\begin{array}{l}\text { 2.2. Kontrol kehadiran di } \\
\text { kampus }\end{array} \\
\begin{array}{l}\text { 2.3. Penyerahan kasus } \\
\text { disiplin. }\end{array} \\
\end{array}$ & $\begin{array}{l}\text { 2.1. Keamanan dalam } \\
\text { ruang kuliah } \\
\text { 2.2. Prosedur kehadiran } \\
\text { kuliah } \\
\text { 2.3. Pengukuran disiplin } \\
\text { kuliah }\end{array}$ \\
\hline $\begin{array}{l}\text { 3.1. Membatasi } \\
\text { kehadiran sekolah } \\
\text { dalam kegiatan } \\
\text { kemasyarakatan }\end{array}$ & $\begin{array}{l}\text { 3.1. Pertemuan dengan } \\
\text { orang tua di kampus. }\end{array}$ & $\begin{array}{l}\text { 3.1. Petemuan dosen } \\
\text { dengan sarikat } \\
\text { berbagai kegiatan }\end{array}$ \\
\hline $\begin{array}{l}\text { 4.1. Kemungkinan } \\
\text { penilaian performasi } \\
\text { guru }\end{array}$ & $\begin{array}{l}\text { Penetapan performasi } \\
\text { dosen }\end{array}$ & Performansi mahasiswa \\
\hline $\begin{array}{l}\text { 5.1. Timbulnya krisis } \\
\text { melalui orang-orang } \\
\text { kontroversi-al dalam } \\
\text { PBM }\end{array}$ & 5.1. Innovasi skala luas & $\begin{array}{l}\text { Perkuliahan di ruang } \\
\text { kuliah }\end{array}$ \\
\hline $\begin{array}{l}\text { 6.1. Penetapan mata } \\
\text { kuliah }\end{array}$ & $\begin{array}{l}\text { 6.1. Program-program } \\
\text { khusus (misal: bilingual, } \\
\text { akselerasi) }\end{array}$ & $\begin{array}{l}\text { 6.1. Menetapkan isi mata } \\
\text { kuliah }\end{array}$ \\
\hline
\end{tabular}

Sumber: Hanson, (1991: 105), sudah diadaptasi.

(2) Security Decisions, [protection, attendence, dicipline], (3) Boundary decisions.

Ketiga kebutuhan tersebut, memuat potensi kepentingan kelompok masing dan kepentingan bersama. Sehubungan dengan itu, Hanson (1991) memetakan ketiga kebutuhan tersebut dalam lingkungan pengaruh rektor, dosen dan contested zone.

Pengalaman dosen berbagai PT yang berstatus mahasiswa Pascasarjana, merefleksi bahwa pada umumnya anggaran kegiatan pengajaran (ternasuk praktikum) tidak pernah digunakan secara maksimal. Hal ini terjadi karena tiga kemungkinan.

(1) Lemahnya kelompok profesional memperjuangkan kebutuhan dalam lingkungan pengaruh mereka atau yang ada dalam contested zone.

(2) Lemahnya kontrol terhadap pengelola unit dalam penggunaan dana. Sehubungan dengan itu, pemetaan kebutuhan PT sangat penting diperhatikan dan diprioritaskan dalam penilaian penyelenggaraan PT. Karena itu, sangat rasional bilamana perumusan kriteria akreditasi PT yang dilakukan BAN-PT mencakup aspek sumber dan pengelolaan dana, di samping: (1) masukan (dengan indikator: mahasis-wa, tenaga, sarana/ prasarana dan kurikulum), (2) Proses (pengelolaan lembaga, 
pengelolaan program dan pengelolaan, pembelajaran dan evaluasi), (3) keluaran dengan indikator hasil kinerja (Depdikbud BAN, 1997; Depdiknas, 2000a:18; dan Depdiknas BAN, 2000b).

\section{MULTIPLE INTELLIGENCES}

Pada prinsipnya, hidup manusia merupakan pengalaman memilih dan meng-gunakan berbagai cara dan kemampuan untuk mempertahankan hidup dan menggapai keinginan, seperti kasus-kasus kehidupan manusia umumnya. Termasuk seseorang yang kuat sekalipun, ketika menghadapi lawan tidak selalu melakukan perlawanan. Ia mungkin melarikan diri atau malah bertekuk lutut dengan kata-kata menyerah atau cara sesuai situasi dan kondisi. Menurut pengalaman tersebut, perjuangan hidup menusia tidak hanya memerlukan kecerdasan intelijensi, tetapi juga kecerdasan emosional dengan cara merendahkan diri.

Sehubungan dengan itu, Gardner (1993) membantah asumsi klasik terhadap konsep inteligensi sebagai kemampuan berfikir yang bersifat tunggal. Memang, Gardner (1999) mengakui bahwa inteligensi berkaitan dengan kemampuan berfikir secara maksimal untuk menyelesaikan atau memecahkan masalah dengan mengguna-kan berbagai daya. Dalam perkembangan terakhir selanjutnya, di samping Goleman (1999), Gardner (1999) secara tegas membantah inteligensi itu sebagai kemampuan tunggal. Ternyata, diketahui bahwa manusia memiliki dimensi inteligensi lain yang berperan dalam penentuan perilaku yang produktif.

Pada mulanya, Gardner (1001: 12) memperkenalkan kemampuan yang dimi-liki individu dengan istilah the seven human intelligences. Namun, melalui hasil-hasil penelitian selanjutnya, Gardner (1999) mempopulerkan berbagai kemampuan individu tersebut dengan istilah multiple intelligences dengan delapan pilar berikut ini (Lusiana, 2001: 6).

1. Lingustic-Intelligence, kemampuan yang sensitif terhadap suara-suara, struktur, makna-makna dan fungsi kata-kata.

2. Logical-Mathematical Intelligence, peka terhadap kemampuan membedakan, logika atau bentuk-bentuk angka, dan menghandel mata rantai alasan.

3. Spatial Intelligence, kemampuan menerima gambar ruang secara akurat, dan menampilkan transformasi persepsi-persepsi orang yang orisinil.

4. Musical-Intelligence, kemampuan memproduksi, dan mengapresiasikan kecepatan, hubungan/puncak, warna nada, dan bentuk-bentuk pengekspresian musik. 
5. Bodily-Kinesthetic Intelligence, kemampuan seseorang mengntrol gerak tubuh dan penanggapan objek-objek dengan keterampilan purna.

6. Inter-personal Intelligence, kemampuan membedakan dan merespons suara hati, temperamen, motivasi dan keinginan orang lain secara tepat.

7. Intra-personal Intelligence, mengakses perasaan yang dimiliki seseorang dan kemampuan untuk membedakan emosi seseorang: pengetahuan tentang kekuatan dan kelemahan yang dimiliki orang lain.

8. Naturalistic Intelligence, menunjukkan keahlian dalam mengenal dan meng-klasifikasi sejumlah spesies (tumbuhan dan hewan) di lingkungannya. Di samping itu, masih ada tiga kandidat intelijen, yakni: (1) existential, (2) spirituality, and (3) moral intelligences yang masih dipertanyakan.

\section{PROSES PENGAMBILAN KEPUTUSAN \\ Strategi Pengambilan Keputusan}

Sebagai kemampuan potensial, peran kedelapan pilar tersebut sudah terbukti dalam interaksi manusia untuk memahami dan mengelola lingkungannya. Sehubung-an itu, peran multiple intelligences dalam setiap keputusan (informal maupun formal) yang diambil untuk menyikapi berbagai situasi dan kondisi menjadi penting, terutama dalam hubungannya dengan kinerja.

Demikianpun, kelangsungan suatu PT sebagai organisasi formal sangat diten-tukan oleh keputusan-keputusan pimpinan yang sebagian besar berada di tangan rektor atau senat. Untuk itu, rektor harus mampu memenej semua sumber daya yang membangun sinergi. Kepadanya dituntut keterampilan manajerial, yakni: conceptual skill, human skill, and technical skill (Sergiovani, et al., 1987: 69-70).

Dengan conceptual skill, rektor mampu memandang semua fakultas dan unit kegiatan dan pelayanan sebagai bagian program pendidikan holistik. Berdasarkan ke-mampuan tersebut, rektor mampu memetakan semua komponen lembaga dengan keadaan dan keterhubungannya secara utuh. Untuk itu rektor harus mempunyai kemampuan: membedakan, logika atau bentuk-bentuk angka, dan menghandel mata rantai alasan yang lebih peka. Tugas tersebut hanya mungkin dilakukan pimpinan yang memiliki kemampuan Logical-Mathematical Intelligence.

Human skill, sebagai aspek keterampilan manajerial kedua, diperlukan untuk mengefektifkan kerjasama, baik secara individual maupun dalam setting kelompok. Keterampilan tersebut berusaha memahami dan menerima apresiasi, empati, dan pertimbangan orang lain sebaik mungkin. 
Sehubungan dengan itu human skill sangat erat kaitannya dengan inter dan intra-personal intelligences (Gardner, 1999), dan kecerdasan emosional (Goleman, 1999).

Menurut analisis Thompson, \& Tuden, strategi pengambilan keputusan perlu mempertimbangkan dua faktor, yakni: (1) apakah terdapat egrimen terhadap tujuan, (2) apakah ada kesepakatan terhadap cara mencapai tujuan tersebut. Kedua faktor tersebut menghasilkan empat tipe strategi pengambilan keputusan. (a) Computational strategies, bilamana terdapat kesepakatan terhadap tujuan dan cara pencapaiannya, (b) judgmental strategy, jika ada kesepakatan pada tujuan, tapi tanpa memiliki pengetahuan cukup untuk menentukan cara pencapaiannya, (c) compromise strategy, jika ada kesepakatan pada cara pencapaian berbagai tujuan, kecuali terhadap tujuan-tujuan yang memiliki prioritas utama, (d) inspirational strategies, bilamana tidak ada kese-pakatan, baik terhadap tujuan maupun cara pencapaiannya (Blau, \& Scott, 1962).

\section{Negosiasi}

Menurut tipe pengambilan keputusan yang dikemukakan, faktor kesepakatan atau agrimen sangat penting. Jelas, pencapaian agrimen terhadap cara pencapaian tujuan sangat menentukan kekuatan suatu keputusan. Dalam konteks tersebut, baik kelompok birokrasi maupun kelompok profesional memiliki kesempatan untuk memenangkan keputusan dengan membangun kesepatan melalui negosiasi.

Mengacu pada pemecahan masalah John Dewey, Sergiovanni, \& Carver (1973) mengemukakan lima asumsi pendekatan berdasarkan konsep rasional, yakni:

(1) pendefinisian dan gambaran problem harus jelas, (2) menemukan, dan menjelas-kan sejumlah alternatif melalui penelitian, (3) mengantisipasi akibat yang akan muncul, (4) memperluas akibat tersebut sesuai tujuan yang akan dirumuskan, (5) me-netapkan urutan alternatif sesuai bobot yang ditawarkan. Dengan memperjelas persoalan, pembeberan data yang menggambarkan alasan bertindak dan akibat tindakan yang akan dilakukan, pertimbangan menjadi lebih akurat, sehingga pengambilan keputusan dapat dilakukan secara meyakinkan.

Dalam konteks tersebut, proses pengambilan keputusan tidak sekedar memu-tuskan dan menafsirkan makna, tetapi meliputi tindakantindakan penting untuk memprediksi operasional keputusan dan akibatakibat pelaksanaannya (Hanson, 1991). Dengan kata lain, pengambilan keputusan hanya mungkin dilakukan melalui analisis untuk 
mepertimbangkan secara cermat keuntungan dan berbagai akibat nega-tif yang mungkin ditimbulkan.

Karena itu, dukungan terhadap suatu keputusan yang diperjuangkan, terletak pada kemampuan kelompok mendefinisikan tujuan dan dampak keputusan yang ditawarkan. Langkah penting lainnya adalah kemampuan mensosialisasikannya, dalam arti tepat orang, momen dan waktu. Untuk menjalankan fungsi secara efektif perlu menugaskan orang khusus yang memiliki kemampuan dan hubungan baik dengan pihak-pihak yang akan dipengaruhi. Dengan kata lain, diperlukan tim kerja (konseptornegosiator) untuk menghasilkan subkoalisi, terutama dalam kubu lawan.

Berkaitan dengan interface birokrat-profesional, dan model lingkungan inter-aksi, kedua belah pihak (birokrat dan profesional) harus memperhatikan sifat-sifat PT yang terkait dengan hal-hal berikut.

1. Timbulnya problem dan keputusan mengikuti perubahan-perubahan lingkungan organisasi (dari kondisi tenang ke kondisi bergejolak).

2. Problem harus diselesaikan dalam interaksi sekitar hubungan lingkungan terkait.

3. Lingkungan pengaruh dibentuk oleh kebutuhan pembuat keputusan khusus.

4. Lingkungan pengaruh dominan ada di sekitar kebutuhan profesional dan birokrat (Hanson 1991).

Dari keseluruhan penjjelasan, tersimpul bahwa faktor-faktor yang berkaitan dengan pengambilan keputusan adalah: (1) sistem informasi, (2) kebutuhan, (3) nego-siasi, (4) agrimen, (5) strategi dan pendekatan, dan (6) produk keputusan, seperti tertera dalam diagram di atas. 
Prosedur Pengambilan Keputusan dalam Contested Zone

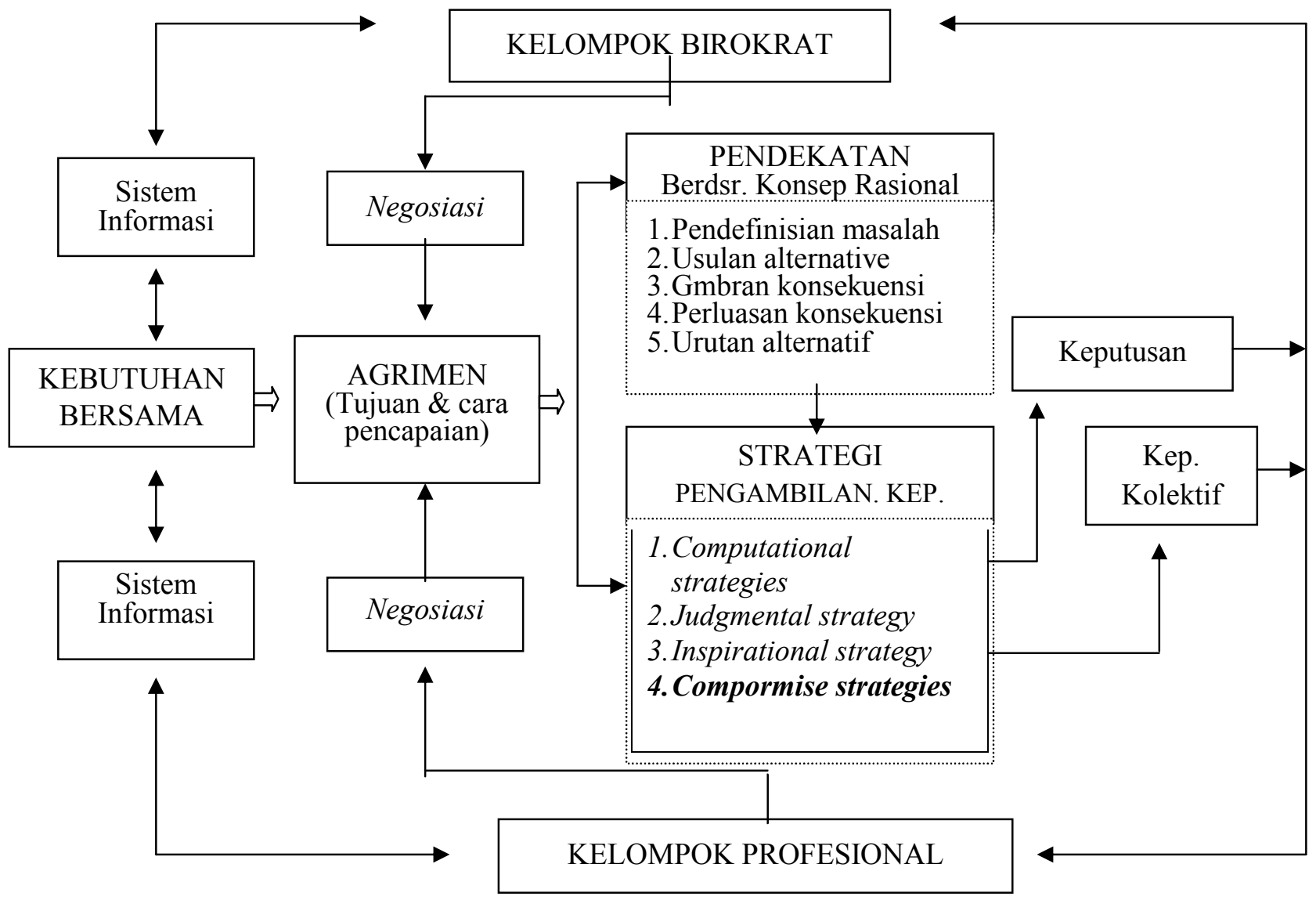




\section{PERAN MI DALAM PROSES PENGAMBILAN KEPUTUSAN}

Di samping informasi dasar, dalam konteks pengambilan keputusan perlu memahami berbagai bagian yang membangun struktur PT. Pada umumnya, PT terdiri dari kelompok inner, yakni birokrat, dan kelompok profesional, di samping kelompok outer, yang terdiri dari masyarakat, Dirjen Dikti, dan dewan penyantun PT.

Kelompok inner, adalah komponen SDM yang berkaitan dengan proses pengambilan keputusan. Terhadap keputusan dalam lingkungan pengaruh contested zone, mestinya tugas kelompok inner memenangkan kepentingan outer, dalam arti masyarakat. Untuk mencapai agrimen terhadap keputusan yang berpihak kepada outer, diperlukan perjuangan melalui negosiasi. Keberhasilan tergantung pada kemampuan tim. Dan ketika menurut pertimbangan sulit menempuh jalan formal, maka jalur informal menjadi pilihan yang menarik. Di sinilah figur-figur negosiator memegang peran penting.

Sehubungan dengan itu, Cyert, \& March Write memandang organisasi itu sebagai koalisi, merupakan gabungan individu yang sebagian mereka diorganisasikan dalam beberapa subkoalisi (Hanson, 1991). Dalam dinamikanya, kelompok-kelompok tersebut dapat berbentuk subkoalisi formal, dan subkoalisi informal. Menurut pengamatan penulis, subkoalisi formal yang berkembang di PT meliputi: (1) team work tingkat universitas, terdiri dari: tingkat pimpinan dan staf ahli, (2) team work tingkat fakultas, terdiri dari: pimpinan fakultas dan kelompok program studi. Sedangkan subkoalisi informal terdiri dari kelompok-kelompok: (1) olah raga, (2) arisan, dan atau (3) kelompok rukun berdasarkan daerah atau alumni, dll.

Dalam praktiknya, hubungan negosiasi akan tumbuh dalam subkoalisi informal yang memiliki anggota kedua belah pihak yang berkepentingan. Hal tersebut dimungkinkan, sifat hubungan subkoalisi informal lebih terbuka, sehingga dapat menumbuhkan rasa saling percaya. Kondisi inilah yang akan dimanfaatkan para negosiator masing-masing untuk mengawali perjuangannya mencapai tingkat agrimen. Tentunya, keberhasilan yang dicapai tidak dapat dilepaskan dari faktor-faktor unggulan, yang oleh Gardner (1999) dinamakan multiple intelligences.

Singkatnya, untuk mencapai tujuan, pimpinan team negosiator harus memiliki keterampilan konseptual. Kemampuan, yang diperlukan untuk menganalisis kebu-tuhan dan mempertimbangkan penerapan pendekatan (berdasarkan konsep rasional) dalam konteks pendefinisian tema kebutuhan dengan alternatif, gambaran konseku-ensi yang realistik, dan penerapan strategi pengambilan keputusan. Kemudian negosiasi 
dilanjutkan dengan mengandalkan human skill. Dengan demikian, pilarpilar MI berperan terus sampai tercapainya keputusan yang memuaskan.

Proses Negosiasi

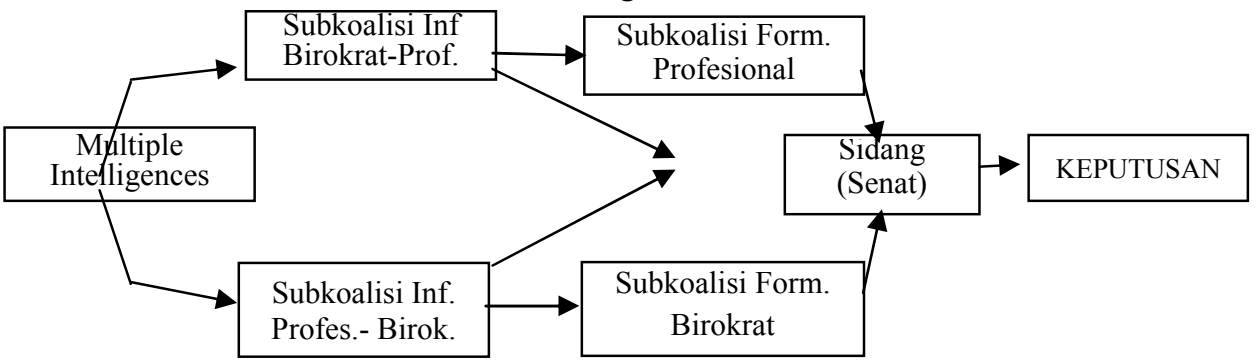

Sehubungan dengan itu, penerapan beberapa pilar MI oleh kedua belah kelompok untuk menghasilkan keputusan produktif sangatlah penting. Menurut Newman, \& Wehlage (1955), keputusan produktif dalam rangka otonomi pendidikan adalah keputusan yang mungkin meningkatkan dukungan ekternal secara maksimal terhadap pembelajaran, seperti dijumpai pada sekolah-sekolah swasta (Watson, \& Supovits, 2001). Sehubungan dengan itu, kelompok profesional sebagai governance berkewajiban memperjuangkan kepentingan pengguna layanan melalui negosiasi yang efektif.

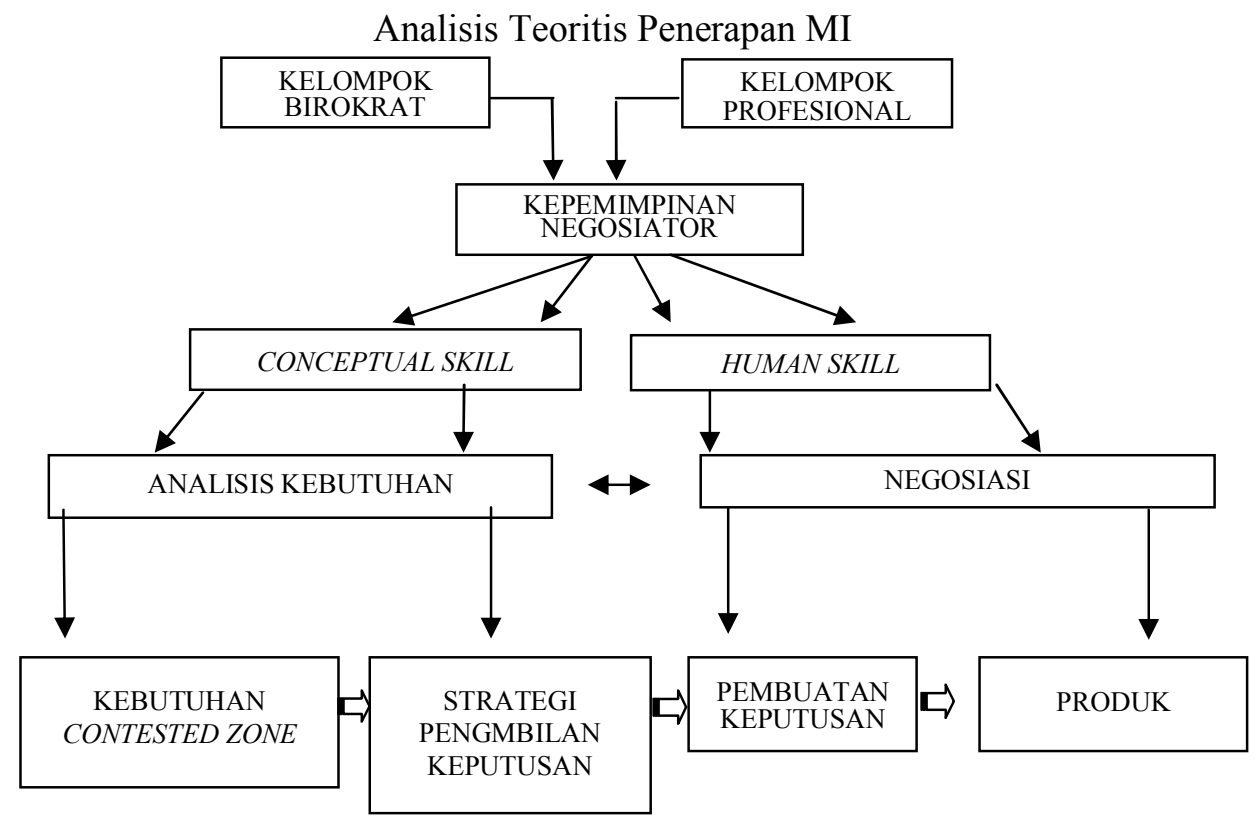




\section{Logical-Mathematical Intell. \\ 2. Spatial Intelligence \\ 3. Language Intelligence}

4. Intra-personal Intelligence

5. Inter-personal Intelligence

6. Language Intelligence

Menurut diagram di atas, prinsip memenangkan negosiasi terletak pada kemampuan penyiapan paket yang bermakna bagi kedua belah pihak. Alhasil, kelompok negosiator harus mengemas kebutuhan yang diperjuangkan itu dalam wujud alternatif pemecahan masalah berdasarkan data yang melandasinya, dan menggambarkan akibat tindakan menurut keputusan tersebut, sehingga prioritas urutan yang ditawarkan sangat jelas. Untuk itu, tim negosiator harus memiliki keterampilan konseptual, sehingga mampu menghasilkan analisis kebutuhan yang mengarah pada kepentingan inner (kedua belah pihak) dan outer (masyarakat).

\section{PENUTUP}

Supaya tidak merugikan semua pihak (inner dan outer) yang bermuara pada kepentingan masyarakat, maka proses pengambilan keputusan terhadap kebutuhan dalam lingkungan contested zone menuntut cara-cara yang bijaksana. Sehubungan dengan itu perlu diperhatikan beberapa hal berikut ini.

1. Proses keputusan dimulai dengan analisis kebutuhan (dalam lingkungan yang akan diperjuangkan) yang bermakna pendefinisian masalah (kebutuhan) secara jelas, penentuan alternatif berdasarkan data (penelitian), pembeberan keuntungan dan akibat-akibat yang akan timbul secara kuantitas dan terbuka, sehingga menunjukkan prioritas alternatif yang jelas. Hasil analisis ini juga berkaitan dengan penentuan strategi pengambilan keputusan yang akan ditempuh.

2. Untuk mencapai keputusan yang dimaksud diperlukan sosialisasi keputusan yang akan diambil sebelum atau selama proses pengambilan keputusan berlangsung. Untuk menjalankan fungsi ini diperlukan negosiator ulung dengan tugas memba-ngun subkoalisi dalam kelompok lawan.

3. Supaya dapat menghasilkan alternatif keputusan yang layak ditawarkan kepada pihak lawan (seperti yang dimaksud butir 1) diperlukan koseptor ulung. Untuk menjalankan fungsi tersebut diperlukan pilar-pilar MI berikut. (1) Logical-Mathematical Intelligence, (2) Spatial Intelligence dan (3) Language Intelligence.

4. Supaya sosialisasi berhasil secara efektif, dalam arti menarik banyak pendukung dari pihak lawan, negosiator memerlukan keterampilan berkomunikasi dan kemampuan memahami diri dan orang lain. Sehubungan dengan tuntutan tersebut kepadanya perlu dikembangkan 
pilar-pilar MI, yakni (1) intra-personal intelli-gence, (2) interpersonal intelligence dan (3) language intelligence.

\section{DAFTAR PUSTAKA}

Blau, Peter M. \& Richard Scott, W. 1962. Formal Organization. San Francisco: Chandler Publishing Company.

Blau, Peter M. \& Meyer, Marshal W. 2000. Alih Bahasa oleh Slamet Rijanto. Birokrasi dalam Masyarakat Modern. Jakarta: Prestasi Pustaka.

Departemen Pendidikan dan Kebudayaan BAN-PT. 1997. Panduan Pengisian Borang Akreditasi Program Studi Jenjang S1. Jakarta.

Departamen Pendidikan Nasional BAN-PT. 2000a. Direktori Hasil Akreditasi Program Studi Jenjang Sarjana (S1). Jakarta.

Departemen Pendidikan Nasional BAN-PT. 2000b. Pedoman Visitasi Akreditasi Program Studi S1. Jakarta.

Gardner, H. 1991. The Unschooled Mind: How Children Think \& How school Should Teach. New York: Basic Books.

1993. Framed of Mind: The Theory of Multiple Intelligences.

New York: Basic Books.

$21^{\text {th }}$ Century. New York: Basic Books.

Goleman, D. 1995. Emotional Intelligence: Why It Can Matter More Than $I Q$. New Yoark: Bantam Books.

--------. 1999. Working with Emotional Intelligence. London: Bloomsbury Publishing.

Hanson, E. Mark. 1991. Educational Administration \& Organization behavior. Bostom: Allyn and bacon.

Lusiana. 2001. Hand Book Mata Kuliah Psikologi Lanjut (DIP.711). Malang: Pascasarjana Universitas Negeri Malang (UM).

Sergiovanni, Thomas J. 1973. The New School Executive: A Theory of Adminis-tration. New York: DODD, MEAD \& COMPANY.

Sergiovanni, Thomas J., et.al. 1987. educational Governance and Administration. New Jersey: Prentice Hall, Inc. Englewood Cliffs.

UU Republik Indonesia Nomor 20 Tahun 2003, tentang Sistem Pendidikan Nasional (Sisdiknas). Bandung: Citra Umbara. 
Watson, Susan, \& Supovitz, Jonathan. 2001. Autonomy \& Accuntability in The Context of standard-based Reform; dalam Journal Education Policy Analysis Archives. Volume 9 Number 32 (pp. 1-22). 